\title{
Maps, Memories and Manchester: The Cartographic Imagination of the Hidden Networks of the Hydraulic City
}

Martin Dodge and Chris Perkins

Department of Geography, University of Manchester

(Email: m.dodge@manchester.ac.uk; chris.perkins@manchester.ac.uk)

\begin{abstract}
The largely unseen channelling, culverting and controlling of water into, through and out of cities is the focus of our cartographic interpretation. This paper draws on empirical material depicting hydraulic infrastructure underlying the growth of Manchester in mapped form. Focusing, in particular, on the 19th century burst of large-scale hydraulic engineering, which supplied vastly increased amounts of clean drinking water, controlled unruly rivers to eliminate flooding, and safely removed sewage, this paper explores the contribution of mapping to the making of a more sanitary city, and towards bold civic minded urban intervention. These extensive infrastructures planned and engineered during Victorian and Edwardian Manchester are now taken-for-granted but remain essential for urban life. The maps, plans and diagrams of hydraulic Manchester fixed particular forms of elite knowledge (around planning foresight, topographical precision, civil engineering and sanitary science) but also facilitated and freed flows of water throughout the city.
\end{abstract}

The survival of these maps and plans in libraries, technical books and obscure reports allows the changing cultural work of water to be explored and evokes a range of socially specific memories of a hidden city. Our aetiology of hydraulic cartographics is conducted using ideas from science and technology studies, semiology, and critical cartography with the goal of revealing how they work as virtual witnesses to an 
unseen city, dramatizing engineering prowess and envisioning complex and messy materiality into a logical, holistic and fluid network underpinning the urban machine.

\section{Introduction}

An apparently inexorable march of progress towards a regulated, commodified, separate and hidden nature, facilitates a process of capitalist accumulation and unproblematic consumption, simplifies but also fixes a single progressive and functional narrative around the memories of place. To begin to complicate this narrative we explore the role that a particular kinds of knowledge and its codification might play in the memorialization of a much more nuanced, partial and contested urban process. Our focus is on hydraulic infrastructures of the modern city and, in particular, how they have been represented in different kinds of maps. On the apparent shift in our vignette (see Box 1), from no mapping, to elaborate, engraved and printed working diagrams facilitating construction and maintenance of large systems, to the control of integrated networks that are themselves flexible and mutable. Our analysis also concerns the ways in which the spatial representations of the hidden city are themselves hidden, and amenable to multiple, mutable and alliterative interpretations, and explores some of the links in this process.

The proceeding argument rests upon a number of important building blocks. Firstly, we need to comprehend the city in a very material sense, to approach the political ecologies of its networks, but also to recognise how urban infrastructure works and who it works for. Secondly, we need to appreciate the distinct technicity that hydraulic infrastructure facilitates but also regulates. In pursuing this analysis the main focus of our argument rests upon an awareness of the politics and practices embodied by, and facilitated though a range of cartographical representations of these networks, the parts they play in Amin and Thrift's (2002) notion of the machinic city, and how the mapping of urban infrastructures is enrolled in different kinds of narratives and memories. 


\section{Box 1}

A pastoral scene. The farmstead in a clearing, a field gently sloping down to a small meandering river. Water trickling unfettered past willows. A young boy collects a wooden bucketful, walks back towards the farm and stops to piss against a tree.

Fast forward. The countryside transmogrified into the city. The river -for it is the same though you would not know it - now flows in a straightened channel, and there disappears beneath the emerging warehouse into stygian gloom. A party of labourers construct a wall from rough-hewn bricks to enhance the canyon like effect downstream, and further restrict the flow. The surveyor looks on, plan in hand, and cloth to mouth to limit the stench. A earthenware pipe spews muck into the drain. A cart carrying night soil moves slowly over a bridge heading out of town. And a woman draws water from the public well at the end of the street.

And onwards. The scene is dark now. Underground. We are in a six foot diameter steel lined tube. Interceptor sewer Number 12. Leading inexorably down and out of the city towards cleanliness in the settling vats and vast filter beds at Davyhulme sewage works. A flowing mass of excrement, industrial waste, grease and runoff. The dirt safely separated from the network of pipes aquaducting chemically purified Lake District rain through the city to consumers who give its chlorinated BSI certified safety little thought. It is statistically measured and mathematically modelled. The video camera monitors the turbid junction with a feeder drain, obviating the need to employ sewer inspectors. And in the United Utilities control room a fleeting digital image is called into being on a screen, the waste network overlain on a street base, its utility plain to see.

Meanwhile the traffic flows once more down Deansgate, free of the water main reconstruction work completed last week and moved onto replace the next section of the ring main. The tourist in the Beetham Tower surveys the urban scene from her hotel window. How clean, and functional it all looks - ordered, fixed and safe. She runs a warming bath and sips her complementary glass of Buxton Mineral Water. 


\section{The political ecology of flows: from sanitary reform to mutable urban infrastructure}

Natures must be harnessed and enrolled for the effective functioning of the city, and it is a form of natural asset that flows through the physical pipe work, valves and sewers.. Of course water has inherent physical properties that makes it very distinct: it flows, is heavy, leaks, can be dangerous when it moves, and yet its mass is now highly controllable and predictable within known parameters. In another sense though the water in the pipe is a social product, manufactured with its natural constituents changed, and after significant labour, capital and technology turned into a commodity to be bought and sold like other commercial goods.

Kaika (2005) argues that both nature and the city in this context are hybrids, neither is purely natural, nor purely social. Instead there is a dialectical relationship between the production of urban living and the production of nature that can be seen in the political urbanization of nature. In her view the great nineteenth century process of public municipal sanitary reform that led to the creation of large scale hydraulic infrastructures costing hundreds of millions of pounds and industrialising large tracts of land, was an attempt to free capitalism from nature's constraints, so as to allow ongoing capital investment, industrial expansion and urban growth.

Others have read the development of sanitary reform as a Foucauldian exercise of biopolitics, part of the process of governing liberalism, producing and regulating the modern subject. Osborne (1996), for example, links the domestic development of sanitation to the evolution of public systems for waste disposal via sewers, and argues it facilitated new modes of regulation of bodily conduct based around newly private spaces and updated notions of cleanliness. Joyce (2003: 66) also highlights the role of sanitary reform as a disciplining device and describes how "anonymous drains, sewers and pipes functioned as the material embodiment of a political division between public and private". Without technology though, and its ability to network water and remove waste, this shift in personal behaviour and urban governance would have been impossible. The physical networks demand attention as well as the material commodities and social conduct they encouraged and facilitated. 
Modern cities depend upon nested layers of infrastructure for their very existence. Amongst other functional roles they transport goods or people, supply energy throughout the city, facilitate communication, monitor citizens or the environment, and of course, deliver drinking water, and dispose of waste. Mapping itself can be thought of as an essential infrastructure (see Dodge and Kitchin 2004; Dodge et al $2009 b)$. It is the last of these: the hydraulic infrastructures that are our concern here.

The form and functions of these hydraulic networks are never static. They offer a technological fix for the demands of different systems of accumulation, that morphs in response to political, economic, social and cultural change, and itself impacts upon the urban condition. Periods of relative socio-technical stability have been identified, for example Gandy (2004) posits the notion of a 'bacteriological city' emerging in the mid-nineteenth century based upon ideologies of cleanliness, and a move away from free market philosophies and towards more rationalised governance of the city through municipal managerialism. Out of this zeitgeist came significant public investment in both sewer systems and drinking water provision, that are the focus of our case study. The infrastructure of the 'bacteriological city' significantly altered lives in the Victorian metropolis, facilitating industrial change, allowing new forms of housing to be developed, and fostering new sensibilities and ways of living (see Kaika 2005; Inglis 2007). Graham and Marvin (2001) also identify a comparable period of stability that they term the 'modern infrastructural ideal', in which an ordered rationally managed city underpinned by state controlled infrastructures emerged from the second half of the nineteenth century and survived until the 1970s. Gandy (2004) argues that the period since 1970 has been characterised by a retreat from this stability, occasioned by privatisation, leading to a more diffuse supply and polarized infrastructure, profit-driven operation, echoing the concerns of Graham and Marvin's (2001) for the future of what they term 'splintering' cities.

Literal infrastructural functions, engineered in concrete and steel, make urban life possible, but urban infrastructures also strongly influence our cultural imaginaries (see, for example, Pike (2007) and Williams (2008)). Gandy (1999) has analysed the cultural resonance of pioneering photographs of the Parisian sewer network in the early 1860 s, highlighting their ability to throw light on the newly emerging but strongly problematic rationalization of the underground city in the Second Empire of 
Napoleon III. Meanwhile Dobraszczyk (2008a) details how London's sewers were celebrated as sublime, but troubling engineering marvels; drawing upon wood engravings published in the Illustrated London News as evidence he argues " $[\mathrm{t}] \mathrm{he}$ construction of the main drainage system created a vast, complex and unsettling spectacle in the city, characterised by scenes of both construction and destruction" (p. 372). In terms of drinking water the photographer Stanley Greenberg has celebrated the engineered beauty bound into the material of the Croton system in New York (Greenberg 2003).

Other research has highlighted how different infrastructures are to a greater or lesser degree visible in the city. Many are a mundane, overlooked and ubiquitous part of the built fabric, most particularly electrical networks. Others are an obvious and sometimes dominant visual force such as the vast railway station sheds and soaring viaducts cutting across Victorian cities. It has been argued that the visual presence of infrastructure itself depends upon, but also engages with cultural economy, for example Kaika and Swyngedouw (2000) discuss how hydraulic infrastructure was celebrated in a fetishized phantasmagoria in its Victorian heyday, but has been rendered progressively opaque in the period 1930-1960. The hydraulic network and its key nodes like impressively large dams and extensive new reservoirs, pump houses and water towers were established as iconic symbols of Victorian engineering progress, celebrated and visited, but have subsequently metaphorically, or literally, disappeared from view, buried underground or hidden as almost secret places in the urban fabric, or in the case of sewage farms outside the cleansed city. Meanwhile newly visible infrastructures like urban motorway schemes and out of town shopping centres have gained cultural power. Unruly river courses have now largely been culverted beneath the city streets. Unpleasant smells and dirt are safely kept away from the sanitized modern city. Mapping the building of these infrastructures was also an important part of the assemblage of the bacteriological city, but to date has been almost completely unresearched, perhaps because of the nature of mapping as a taken for granted discourse (although see Dobraszczyk 2007 and 2008b for incisive exceptions to this omission).

Infrastructures that facilitate flow are separate from, but integral to the fabric and process of the city, and are secured for the wellbeing of citizens, by careful control 
and regulation. We are only rarely now granted legal access to these sites, which are carefully segregated from other utility network functions. A regulation involving technologies, social actors, labour, natural forces, capital, cultural imaginaries and affects, excludes and precludes everyday experience of these places, but also conveys a reassuring sense of permanence and dependability. Hydraulic infrastructure appears ordered, waste-water is flushed away, clean water emerges seemingly without effort from the taps. This order masks a fragile assemblage, often emerging as a partial solution to tensions (see Gandy 1999 for a consideration of the conflicted ideologies beneath the construction of Hausmann's Parisian sewer network) and Kaika 2005 on water shortages in Athens). The everyday dependability of hydraulic infrastructural networks may also be uncertain. Flows may exceed a system's capacity, leading to a flash flood through storm overflows. Sewers may collapse disrupting flows in other surface infrastructures. There may be explosions arising from the confinement of sewer gases. Offensive odours may escape from the system. Pipes may burst leaking water and in turn impacting on integrity of other underground plant leading to water shortages, and mass wastage from leakages. The water in the tap may not be clean and as safe was its clear visual appearance implies and the growth in sales of bottled water speak to this fear. Anxieties about the permanence of infrastructural solutions to the urban condition generates much debate during the era of 'splintering urbanism' (Graham and Marvin 2001), paralleling the concerns of sanitary reformers about the lack of infrastructure in the years before the emergence of 'bacteriological city' later in the $19^{\text {th }}$ century (Platt 2005).

Flows through the infrastructure bind places together, or make physical pathways between a city and its hinterland stretched out at varying scales. They may be rhythmic and often repeated, like surges in water demand at particular times of day; or have directional qualities, most especially the carefully monitored and gravity driven exit of water and waste products downward through sewers or out along culverts. Or they may be much more random such local weather patterns and the amounts of runoff flowing through a culverted stream across the city. Tracking and mapping these flows, and relating them to infrastructural capacity has been scripted as an engineering challenge (see Read and Vickeridge 1997). Indeed, almost all research on urban hydraulic infrastructure has implicitly adopted this kind of functionalist analysis, rather than acknowledging the potential of more socially hybrid and 
relational understanding. Only recently have cities been theorised as emergent, hybridised and porous entities, characterized by mutable interconnected, rhizomatic forms, rhythmic processes, flows and uneasy fractured assemblages of socio-spatial processes (see Amin and Thrift 2002). Our analysis suggests that studying representations of the often buried, hidden but interconnected aspects of hydraulic infrastructure particularly invites this kind of Deleuzian view of the city.

Given this contingent rethinking of infrastructures, cities and mapping, with a shared concern for a local process, it can be argued that detailed case studies are needed of particular kinds of maps, in particular places and at different times. Here we focus on revealing some of the memories that can be evoked in the mapping of hydraulic infrastructures of Manchester, the emblematic 'Shock City' (Platt 2005) of the industrial revolution. Before offering some narrative interpretation of these 'visual stories' we need to explore exactly what was mapped and document the nature of these spatial representations in Manchester.

\section{Historic trajectories of the hydraulic infrastructure in Manchester}

Since the mid $18^{\text {th }}$ century the gradual development of Manchester's hydraulic infrastructures has focused on modifying existing drainage in the city, to allow wastewater to be removed and to try to eliminate, or at least regulate, flooding, but also on devising large-scale engineering solutions to bringing a reliable supply of drinking water to widening segments of the populous. Substantial material modifications to natural systems included physical culverting of river courses, construction of sluice systems, significant channel straightening or canalisation, and designation of flood overflow zones. Particularly from the mid $19^{\text {th }}$ century onwards large capital programmes purchased land beyond city boundaries for source reservoirs and extensive water catchment areas and built large earth dams, along with networks of smaller storage reservoirs, filtering works, pumping stations, ring mains and distribution systems. More recently chemical water treatment facilities have been built to deliver improvements in drinking water quality along with more rigorous requirements in processing sewage. Responsibility for these schemes shifted from relatively small private companies to local public control by municipal authorities in the mid nineteenth century. In 1973 the giant regional public water company North West Water was established, which was privatised in 1989 and now operates as the 
regulated private utility company United Utilities. Infrastructural development and expansion partly parallels population growth and geographical extensions of the city boundaries, but was also spurred by changing expectations of basic sanitary provision and how this should delivered and managed. The incremental growth of layers of infrastructure has resulted in a complex assemblage covering many thousands of kilometres of physical pipework and tunnels, myriad mechanical objects, buildings and other kinds of managed objects.

Considering the development of one aspect of this assemblage, the waste water system in more detail, Read (1997a) identifies four distinctive periods of sewer construction in the city, on the basis of the engineering characteristics and network scale: an early period of culverting, followed by development of small sewers feeding into local water courses, and two phases of construction of larger scale interceptor sewers that transported the effluent for distant disposal or treatment. This classification is based upon an earlier overview of the history of the system produced during the period of his tenure as City Engineer. In this report, Geoffrey Read (1979) argues that the earliest sewers in the city were culverted natural watercourses constructed in the eighteenth century, which have subsequently been described and charted by Ashworth (1987) as 'lost rivers' (Figure 1). The function of culverting was to facilitate rapid removal of rain-water falling onto the impervious tarmaced surfaces of the modern city, but also allow urban development above the former streams. The first artificial sewers were a limited, shallow and discontinuous series of buried drains constructed under the ethos of the Police Commissioners between 1792 and 1828 which discharged directly into the nearest river and functioned as a local and limited extension and modification of the existing pre-industrial drainage works. Until the 1840s sewers were predominantly U-shaped and brick constructions, only rarely being accessible via manholes, and usually built to a diameter of under a metre (Read 1979).

Sewer construction picked up and paralleled the rapid urban expansion of the city in the period from 1830 to $1860(\operatorname{Read} 1979)$. Lower level underground construction took place and purpose-built sewers began to carry polluted water some distance to the river outfalls, with sewers constructed under existing streets (Figure 2). The pressures of development and population growth encouraged engineering innovation 
and brick construction techniques gradually came to be supplanted by manufactured moulded clay pipes, usually ovoid or egg shaped. This encouraged a better flow, but jointing was prone to failure. The 1840s and 1850s were the period of most rapid growth of the system and a gradual rise in the amount of domestic sewage along with increasing industrial waste led to a progressive decline in the quality of Manchester's river water quality, in particular around outfalls (Wilson 1990). Wilson explores why nearly fifty years were to pass before Read's (1997a) third period saw a partial solution to this problem, with the construction of a series of twenty-one deeper and much larger interceptor sewers, designed to carry effluent to two huge outfall sewers that led out of the city to a newly constructed sewage treatment works at Davyhulme, lying in open country next to the Ship Canal (itself another massive project of Victorian hydraulic engineering). Davyhulme was constructed in 1894 and with subsequent development became one of the largest sewage treatment plants in Europe. Some 56 kilometres of these brick 4.5metre diameter sewers were laid, and connections made between this and the local networks between 1903 and 1914 (Read 1979). A final phase, from 1911 onwards, saw a second batch of 16 new interceptors constructed, work on which was in the main completed by the 1930s. This main drainage system was, however, not designed to cope with storm flows, which were allowed to overflow into rivers. Its capacity is still limited and construction qualities of the local network were until the 1870s not up to contemporary standards (Read 1979).

With a steady or sometimes declining population the focus for Manchester's local authorities was on maintaining this network in the second half of the twentieth century. The oldest parts of the local network became increasingly problematic in the 1970s with a series of very visible and disruptive sewer collapses in the city centre (Read 1997b) and major investment has been required to maintain water quality and where necessary reconstruct. The system requires frequent maintenance, and lies unnoticed beneath Manchester's streets, apart from occasional explosions from the build up of sewer gases (Figure 3).

The second focus for hydraulic engineering in the city lay with drinking water supply. In the early years of industrial expansion there was only a limited engineering intervention to provide clean water to the city and until the middle of the nineteenth 
century Manchester relied upon local sources of water, from wells, rainwater collection systems, or the nearest stream. However, the dramatic environmental degeneration documented by Douglas et al. (2002) and Platt (2005) meant rapidly increased the amount of domestic effluent and industrial pollution in this runoff and consequently the quality of river water declined to such an extent that by the 1830 s de Toqueville commented on "Manchester's fetid muddy waters, stained with a thousand colours" and likened the whole city to a cesspool (cited in Ritvo 2009: 45). In the first half of the $19^{\text {th }}$ century the private Manchester and Salford Waterworks Company conspicuously failed to improve this situation throughout its 35 year existence, with demand for water frequently outstripping their unreliable supply system, and even by 1846 piping only provided sporadic clean water to around a quarter of households (City of Manchester Waterworks Committee 1974). Not until 1847 when a bill authorised local control of the company under public ownership did a realistic mechanism for improving the situation become possible. This saw the municipal city corporation boldly reaching out well beyond its civic boundaries into the upland hinterland of the Peak District, and enacting engineer John Frederic Latrobe Bateman's ambitious schemes for reservoirs in the Longdendale valley, connected to the city by underground eighteen mile long aqueduct, and a series of service reservoirs. The first Pennine water reached the city in 1851 flowing under gravity, and the scheme grew in steps to become a impressive chain of seven reservoirs covering about 500 acres, was finished by 1871 (Bateman 1884) and continues to supply water, working much as it was initially designed (Figure 4).

As the reservoirs in Longdendale were being planned and built demand for domestic water increased. More homes were connected to a piped supply and it was becoming clear that sources nearby in the Peak District would soon be inadequate. Thirlmere in the Lake District was proposed as a second and even longer distance addition, in the face of considerable opposition from a nascent conservation movement (Ritvo 2009). The Act authorising the scheme was passed in 1879, and the project to dam the Lake, raise its level, and construct an ambitious 96 mile aqueduct to the city was completed by 1894 (Harwood 1895). Subsequent schemes in the Lake District saw Haweswater dammed, raising its water levels significantly, and the construction of a separate aqueduct south to the city (Figure 5). Subsequently, connections to other sources in Cumbria have augmented this supply. 


\section{Mapping the hydraulic assemblage}

Vast amounts of specialist mapping of these major infrastructural projects were compiled, some of which survives in archives and in published reports submitted to council committees, or as promotional booklets and technical monographs about the various schemes. Different genres of spatial representation may be identified with specifications closely related to an often very specific role and scale of display. At smaller scales geographical maps envision the state of networks at different dates, whilst at larger scales more specialist plans detail the status of particular parts of the hydraulic infrastructure: sewer maps, and detailed architectural and engineering crosssectional drawings of dams or flood control systems reveal strongly targeted views of the system, but also suggest something of the different stories of the city, in which they played at times significant roles. Remarkably little has been written about the mapping of urban hydraulic infrastructure. These maps receive barely a passing mention in standard guides to maps for local history (e.g., Hindle 1988; Mitchell and Beech 2006), or in the journal literature where even the critical literature tends to regard them as self-evident icons of fact (see, for example, Gandy 1999). They sit overlooked in collections where they are incomplete, often hard to access and poorly catalogued, a somewhat hidden reminder of a largely hidden infrastructure. Detailed contemporary mapping of water supply and subterranean facilities is typically held as confidential with overtones of security risks in their release, exacerbating the rather secret nature of the cartographic record. In this section we describe some of the characteristics of these maps, as a necessary first step before moving on to offer an interpretation of their significance.

Numerically the sewer map comprises by far the most significant mapping effort, perhaps not surprising given the geographical extent of the network. John and Guest (1986) provide the only useful introduction to these documents and the following section draws heavily on their paper. By 1986 some 25,000 drawings and related documents survived in the archives of working records of what was then the City Engineers Department of the City of Manchester Corporation, where they were either stored in large plan books or as rolled drawings ranging from under a half to three metres in size. Many were already in very poor condition by the time the City Engineers photographed them in the late 1980s for storage on microfilm and 
established a retrieval system to access information they contained. The fate of the originals of these plans is now unknown but they are likely to have been destroyed.

The majority of these sewer plans are simple but high quality monochrome documents, usually charting the line of an individual sewer and a sectional view (Figure 2), but also sometimes recording the name of the draughtsman, surveyor and contractor, reflecting a strong degree of professional pride in quality of drawings. From these plans it is possible to identify the type of sewer, its construction details, and the date of installation. No plans seem to have survived before 1829 . They sometimes show additional information like street or building layout, or the relation of the sewer to other adjacent underground utility information. Occasionally these plans were supplemented by hand colouring or hand written annotations. The rationale for their production seems to have been to guide construction of the individual sewer and provide a record of what is in the ground for subsequent road maintenance. In addition to the individual detailed sewer plans there are examples of mapped overviews of the local sewer network, usually overlain onto an existing Ordnance Survey base (Figure 6). This sparse style of technocratic schematic evokes in hard copy the current sewer digital map database, that now resides in the control of United Utilities as a digital layer draped across an OS MasterMap backdrop (Figure 7). Smaller scale sewer maps also exist. For example, to map out the location and interrelations of the much larger main drainage system instigated in the programme of interceptor sewer construction in the early twentieth century (Figure 8). Produced as a promotional display to persuade council to merit of the capital investment and the scale of engineering achievement. More schematic representations of the network and logical processes evoke notions of a wiring diagram, focusing as they do on interconnections and topology, instead of relations to geographical features (Figure 9).

At the geographical extremity of the sewage system there are many detailed plans of the Davyhulme Sewage Treatment Plant, produced by the Rivers Department of the City corporation as part of its planning process, but also during the ongoing and subsequent modernisation of the plant (Figure 10).

The laying of water pipes across the city involved much less excavation and detailed plan records of the historical installation of this network do not seem to have 
survived. Coloured overview maps at a smaller scale chart the changing distribution of water across the city though (Figure 11), and map the re-scaling of supply from Longdendale and the various Lake District Schemes. The detail of these schemes is recalled in elaborate colour and celebratory detail in the volumes published by Bateman (1884) and Harwood (1895) (for example, Figures 12 and 13). Here the rationale for publication seems to be much more one of celebrating the career of the protagonist authors, and the elaborate engraved cross-sectional plans of dams and reservoir chart a very different motivation from the much more prosaic working sewer maps (Figure 14). Various parliamentary proposals also chart the detail of these schemes in proposal form, focusing in particular on the effects on road routes, details of land ownership and needs for compulsory purchase (Figure 15); the format of these proposal plans in large folios, on heavy paper, with a very particular aesthetic of graphics and copious amounts of white space speaks to the need for a clear display, but also connotes the seriousness and significance of the scheme being proposed for Parliamentary approval.

Maps sometimes depict extravagant drainage proposals that were never enacted, (see for example the proposal to divert and then drain a section of the River Irwell to allow tram transport along its dry bed; Figure 16). Media mapping of the infrastructure markets the significance of changes to the system for consumers and (for the last two decades) share-holders alike. Contemporary 'celebratory' histories reprint these maps and reflect a rising local historic interest in the hydraulic past (see Quayle 2006; Hoyle and Sankey 1994).

\section{Reading the cartographic imaginaries of the hydraulic mapping of Manchester}

\subsection{Precise and permanent portraits of progress, and professionalism}

On one level these maps, plans and engineering diagrams might simply reflect many of the values associated with a progressive view of the history of cartography. After all, the large-scale Victorian urban engineering projects were above all else imbued with the spirit of progress: they made the future possible. Histories of cartography in this perspective script changes in the medium as an inevitable progression towards greater precision, and more mapped knowledge, painting a linear narrative of innovation, improved techniques and heroic advances (see, for example, Wallis and 
Robinson 1987). This kind of scientifically-grounded perspective all too often presents the map as a universalist and thoroughly pragmatic tool to represent the world, always separate from it, and a device that consistently simplifies its complexity, routinely deployed to carry out practical work. The western model of cartographic progress is assumed to be 'better' than alternatives. In this model every human being can map (see Blaut et al 2003), everywhere can and should be mapped, and there are standardized ways of mapping and approved cartographic formats. Maps become objects embodying technocratic knowledges, a part of visual culture, but where the vision is employed to encode $u s e f u l$ knowledge, even if seen as rather mundane sort of knowing. Surveyors of reservoir sites, engineers plotting aqueduct routes and draughtsmen inscribing sewer systems in this view simply used a representation of 'reality' to communicate information about the world; and their ability to achieve this task has improved as advance followed technical advance. They also create an aesthetic: a kind of scientific portrait of what can be made to take place. Draughtsmen enacted their surveys to communicate a simplified views of what engineering knowledge made possible. Many of the contexts in which mapping has been deployed are, undoubtedly useful: maps of the hydraulic infrastructure are now more detailed. Technologies of production have changed. The manuscript map was supplanted, in turn, by copper engraving, offset lithography and photographic reproduction certainly facilitated the making of the huge numbers of sewer maps needed to cover Manchester. The digital image of a water supply is more useful than the paper copy. It can, for example, be associated with mathematical models of flow rate, to predict in which circumstances, and where a storm overflow will occur. Excavation can be better planned to minimise impacts on urban traffic. Data $d o$ proliferate, collected from GPS receivers, high resolution satellite images, and automated sensors (e.g., remote rain gauges sending measurements back via radio).Geographic Information Systems facilitate their combination and display by utility companies. New visualisation techniques do allow different things to be imagined. And this utility was partly confirmed by the connotations of mapping. The fact that something was mapped gave it a sense of permanence, a tangible existence. Hydraulic infrastructure was on the map literally and metaphorically, even if it couldn't be seen on the surface. 
However, this progressive narrative largely ignores the wider social contexts and the more complex nature of the work that the map facilitates. It significantly oversimplifies everyday mapping practices as well. Cartographic representation (like the space of the city) has been rethought in many different and productive ways since the heyday of scientific cartography in the late 1970s (see Dodge et al 2009a).

\subsection{Power and profit with philanthropy and probity}

Social constructivist alternatives to conceptualise the nature of cartography offered by scholars such as Harley (1989) and Wood (1992) focused attention away from the maps as artefact and onto the political work the object achieved. The power of maps lay in their ability to affirm with certainty a link between place and an interest (Wood 1992). Maps of Manchester's hydraulic infrastructure in this view can be seen to embody certain interests above others, often associated with governance or control of the city and its functions. A Foucauldian reading of their role saw them as a necessary part of the great sanitary re-imagining of the city, necessary because they allowed new modes of rational management of human subjects to be instigated. These maps did not directly discipline their subjects, but they certainly underpinned construction and maintenance of infrastructures which were central to the 'rule of freedom' (Joyce, 2002). Municipal governance and the ethos of civic improvement required new ways of living to be fostered, hydraulic infrastructure were one of the key mechanisms for delivering urban change and these large-scale schemes (which took years to realise) had to be imagined by mapping their possibilities.

Profit was made in and by the process of mapping. Profit for the manufacturers of pipes, for the water companies, and for the local authorities able to charge water rates once natural supplies had been imagined into real commodities in the mapping. Profit for the surveyors, and draughtsmen employed to visualise what could be achieved as well. Profit for the engineering contractors and suppliers of materiel using mapping. And profit for the raft of commercial enterprises that came to depend on the new urban infrastructures that are more affordable and reliable. So in this view specialist genres of cartography were invented to solve particular social tasks, which were closely associated with the continuing process of capital accumulation. The various kinds of network cartography, riparian charts, promotional diagrams and sewer maps described above were each examples of power-knowledge, deployed to achieve the 
social work of fostering a more genteel, cleaner, and healthy city, or promoting the interests of one point of view or another. But they all depended on a strongly economic motive.

Semiological approaches to cartography have allowed meanings of coded imagery to be unpacked and apparently neutral authoritative genres of representation may be unmasked as myth (see Wood and Fels 1986 on maps; and Medway and Clark 2003 on building design plans). This kind of reading of engineering drawings or individual sewer maps might, for example, highlight their pared down visuals rendering plan view and section, as a denial of human context, and argue the simplification and omission of social city reifies the civil engineering and functional status of the construction. A schematic network plan might be unpacked as a reduction of the emergent hybridity of the city to a knowable, controllable physical system, through which could flow unmentionable outcomes of metropolitan life. The hidden function in the diagrams might then be seen to mirror the literal hiding of the infrastructure beneath the city streets. On the other hand the lavish coloured plans of reservoir infrastructure published by Bateman (1884) and Harwood (1895) might be read as affirming the power and achievement of the heroic figures funding their compilation and publication, whilst also celebrating the precision of the engineering science and the aesthetic skills of the engravers and colourists.

The construction of this visual knowledge itself was disciplined: specialist skills and bureaucracies were needed to maintain and devise these coded artefacts of cartographic progress and developed their own professional visions (Goodwin 2002). Cartography and surveying, and more recently remote sensing and Geographic Information Science invented themselves and standardized practices to protect their emerging disciplinary power. These specialist expert fields played a role in standardizing the visual forms through which they expressed their ideas. City authorities traded on this emerging specialization in the tendering processes for the contacts to build interceptor sewers, where expert visualisations of schemes in mapped form were important rhetorical devices deploying established, visual and expert knowledge to win the contract (see Dobraszczyk 2007, 2008b for an illustration of this process in London). 


\subsection{Performance and practice}

More recent theorisation has shifted attention away from the cartographic object, and from the political work it achieved, towards the ways in which mapping might be performed (Crampton 2009), and towards the cultures and everyday contexts in which it is deployed (Perkins 2008). Several different kinds of critical cartography are emerging that can usefully interpret the processes of deploying hydraulic mapping of Manchester. Contexts around mapping becomes crucial to the deep explanation, the social activity in which the map is enrolled matters, the places where it is deployed makes a difference, and the historical moment it is part of constitutes the memories, meanings, actions and work occasioned in this unfolding process. So instead of a map representing an interest, or necessarily carrying immutable knowledge to new location (see Latour 1987), it is seen increasingly, as taking on an agency of its own, with a social life, called into being when the need arises to be part of a particular social task (Del Casino and Hanna 2005; Kitchin and Dodge 2007).

So the same map might be deployed to help build a sewer, maintain it, to recall a sewer repair task, or to plan an imagined new extension to the network. For the draughtsman it might have been the means to gaining a living wage but also a channel, through which aspects of creativity could be displayed: a source of pride. It might now be actively enrolled to subvert or imagine alternatives, sometimes for fun and in play as well as for work, perhaps in an illegal urban exploration of what is now a hidden part of the urban fabric. It might be acquired by a collector, amassing a private accumulation of materials, fetishistically knowing the past through a quest for placed proxies of its achievements. To the archivist in whose collection in whose collection it now resides it might be an artefact to be guarded with care or as a source of worry given space constraints and budgets cuts leave them embarrassingly uncatalogued. It might become 'lost' in a drawer gathering dust, be framed as a 'pretty picture' on a boardroom wall, or used as a practical tool by contemporary engineers grappling with a problem. It will be part of different narratives (see Pearce 2008), evoking different affective powers (see Kwan 2007). The mapping of urban hydraulic infrastructure in Manchester here becomes so much more than either a scientific transcription, or purely a political device. The frequently quoted view of the rhizomatic nature of cartography is seems particularly appropriate for these maps of hidden but often buried infrastructures: 
" the map ..... constructs an unconscious.... is open and connectable....detachable, susceptible to constant modification. It can be torn, reversed, adapted to any kind of mounting - reworked by an individual group or social formation" (Deleuze and Guattari 1987: 12).

\section{Epilogue}

We started this reflection on mapping with a simple vignette, that sought to evoke a sense of some of the places and times in which mapping of the hydraulic infrastructures of Manchester might have been. Our argument distinguishes mapping as a process strongly separate from other aesthetic endeavours, that strive to make powerfully naturalized and tangible scientific visualizations of the engineered environment. We conclude, however, that different groups will deploy the same spatial representation in very different ways and that immutability as a figure explaining the role of mapping as a discourse is increasingly being replaced by mutability. Neutral separation of maps as representations fails to either account for the social power they evoke, or their active and powerful embodied performance calling different cities into being. The many different Manchesters matter in the construction of memories of the city, but mapping itself is an active agent in many fields of social life. So rethinking hydraulic mapping of the city echoes rethinking the urban as practice and its infrastructures as emerging within a situated and geographically specific political ecology.

\section{Acknowledgements}

We are grateful to Helen Lowe and her colleagues in local studies in the Manchester City Library for providing access to a range of mapping material essential to this work. Thanks also to Gwen Jolley at the Greater Manchester County Records Office for helping us to access the archive of historic sewer maps for Manchester. The research underlying this paper has been partly supported by Manchester Geographical Society. 


\section{References}

Amin, A. and Thrift, N. 2002 Cities: Re-Imaging the Urban. Polity: Cambridge. Ashworth, G. 1987 Lost Rivers of Manchester. Willow Publishing: Altrincham.

Bateman, J.F. 1884 History and Description of the Manchester Waterworks. T.J. Day: Manchester.

Beech, G. and Mitchell, R. 2004 Maps for Family and Local History. National Archives, London.

Blaut, J.M., Stea, D., Spencer, C. and Blades, M. 2003 "Mapping as a cultural and cognitive universal", Annals of the Association of American Geographers 93(1): $165-85$.

City of Manchester Waterworks Committee 1974 Water for the Millions: Manchester Corporation Waterworks 1847-1974. Manchester City Council: Manchester.

Crampton, J.W. 2009 "Cartography: performative, participatory, political”, Progress in Human Geography 33(6): 840-48.

Del Casino, V.J. and Hanna, S.P. 2005 “Beyond the 'binaries': A methodological intervention for interrogating maps as representational practices", ACME: An International E-Journal for Critical Geographies 4(1): 34-56.

Deleuze, G. and Guatarri, F. 1987 A Thousand Plateaus: Capitalism and Schizophrenia. University of Minnesota Press: Minneapolis, MN.

Dobraszczyk, P., 2007 “Mapping sewer spaces in mid-Victorian London”, in Campkin, B. and Cox, R. (eds.) Dirt: New Geographies of Cleanliness and Contamination. I.B. Tauris: London, pp. 123-137.

Dobraszczyk, P., 2008a "Sewers, wood engraving and the sublime: picturing London's main drainage system in the Illustrated London News, 1859-62", Victorian Periodicals Review 38(4): 349-78.

Dobraszczyk, P., 2008b "Image and audience: contractual representation and London's main drainage system", Technology and Culture 49: 568-98.

Dodge, M. and Kitchin, R., 2004 “Charting movement: mapping Internet infrastructures", in Hanley, R.E. (ed.) Moving People, Goods, and Information in the 21st Century: The Cutting-Edge Infrastructures of Networked Cities. Routledge: New York, pp. 59-85.

Dodge, M., Kitchin, R. and Perkins, C. (eds.) 2009a Rethinking Maps: New Frontiers in Cartographic Theory. Routledge: London. 
Dodge, M., Perkins, C. and Kitchin, R., 2009b "Mapping modes, methods and moments: a manifesto for map studies", in Dodge, M., Kitchin, R. and Perkins, C. (eds.) Rethinking Maps: New Frontiers in Cartographic Theory. Routledge: London, pp. 220-43.

Douglas, I., Hodgson, R. and Lawson, N. 2002 "Industry environment and health through 200 years in Manchester", Ecological Economics 41: 235-55.

Gandy, M. 1999 "The Paris sewers and the rationalization of urban space”, Transactions of the Institute of British Geographers 24(1): 23-44.

Gandy, M. 2004 "Rethinking urban metabolism: water, space and the modern city", City 8(3): 363-79.

Goodwin, C. 1994 “Professional vision”, American Anthropologist 96(3): 606-33.

Graham, S. and Marvin, S. 2001 Splintering Urbanism. Routledge: London.

Greenberg, S. 2003 Waterworks: A Photographic Journey Through New York's Hidden Water System. Princeton Architectural Press: Princeton, NJ.

Harley, J.B. 1989 “Deconstructing the map”, Cartographica 26(2): 1-20.

Harwood, J.J. 1895 The History and Description of the Thirlmere Water Scheme. Blacklock: Manchester.

Hindle, P.B. 1988 Maps for Local History. Batsford: London.

Hoyle, N. and Sankey, K. 1994 Thirlmere Water: A Hundred Miles, A Hundred Years. Centwrite: Bury.

Inglis, D. 2007 "Sewers and sensibilities: the bourgeois faecal experience in the nineteenth century city", in Cowan, C. and Steward J. (eds.), The City and the Senses. Ashgate: Aldershot, pp 105-30.

John, S. and Guest, P. 1986 “Mapping Manchester's sewers: The Engineering Archives Project", Manchester Region Local History Review 2(2): 33-37. Joyce, P. 2003 The Rule of Freedom: Liberalism and the Modern City. Verso: London.

Kaika, M. 2005 City of Flows: Modernity Nature and the City. Routledge: London.

Kaika, M. and Swyngedouw, E. 2000 "Fetishizing the modern city: the phantasmagoria of urban technological networks", International Journal of Urban and Regional Research 24: 120-38.

Kitchin, R. and Dodge, M. 2007 "Rethinking maps”, Progress in Human Geography 31(3): $331-44$ 
Kwan, M-P. 2007 “Affecting geospatial technologies: towards a feminist politics of emotion", The Professional Geographer 59(1): 22-34.

Latour, B. 1987 Science in Action. Harvard University Press: Cambridge, MA.

Manchester Corporation. 1934 How Manchester is Managed.

Medway, P. and Clark, B. 2003 "Imagining the building: architectural design as semiotic construction", Design Studies 24(3): 255-73.

Osborne, T. 1996 "Security and vitality: Drains, liberalism and power in the nineteenth century", in Barry A., Osborne, T. and Rose N., (eds.) Foucault and Political Reason. University of Chicago Press: Chicago, pp. 99-121.

Pearce, M.W. 2008 "Framing the days: place and narrative in cartography", Cartography and Geographic Information Science 35(1): 17-32.

Perkins, C. 2008 “Cultures of map use”, Cartographic Journal 45(2): 150-58.

Pike, D.L. 2007 Metropolis on the Styx: The Underworlds of Modern Urban Culture, 1800-2001. Cornell University Press: Ithaca, NY.

Platt, H.L. 2005 Shock Cities: the Environmental Transformation and Reform of Manchester and Chicago. University of Chicago Press: Chicago.

Quayle, T. 2006 Manchester's Water: The Reservoirs in the Hills. Tempus Publishing: Stroud.

Read, G.F. 1979 Manchester's Main Drainage System Past and Present. City of Manchester Highways Committee: Manchester.

Read, G.F. 1997a "Development of the national sewerage network", in Read, G.F. and Vickeridge, I. (eds.) Sewers: Rehabilitation and New Construction. Arnold: London, pp. 22-40.

Read, G.F. 1997b “The problems of sewerage dereliction”, in Read, G.F. and Vickeridge, I. (eds.) Sewers: Rehabilitation and New Construction. Arnold: London, pp. 41-68.

Read, G.F. and Vickeridge, I. 1997 Sewers: Rehabilitation and New Construction. Arnold: London.

Ritvo, H. 2009 The Dawn of Green: Manchester, Thirlmere and Modern Environmentalism. University of Chicago Press: Chicago.

Wallis, H. and Robinson, A. 1987 Cartographical Innovations: An International Handbook of Mapping Terms to 1900. Map Collector Publications in association with the International Cartographic Association: Tring.

Williams, R. 2008 Notes on the Underground. MIT Press: Cambridge, MA. 
Wilson, A. 1990 Technology and Municipal Decision Making: Sanitary Systems in Manchester 1868-1910. Unpublished PhD Thesis, University of Manchester.

Wood, D. and Fels, J. 1986 "Designs on signs: myth and meaning in maps", Cartographica 23(3): 54-103.

Wood, D. 1992 The Power of Maps. Guilford Press. New York. 


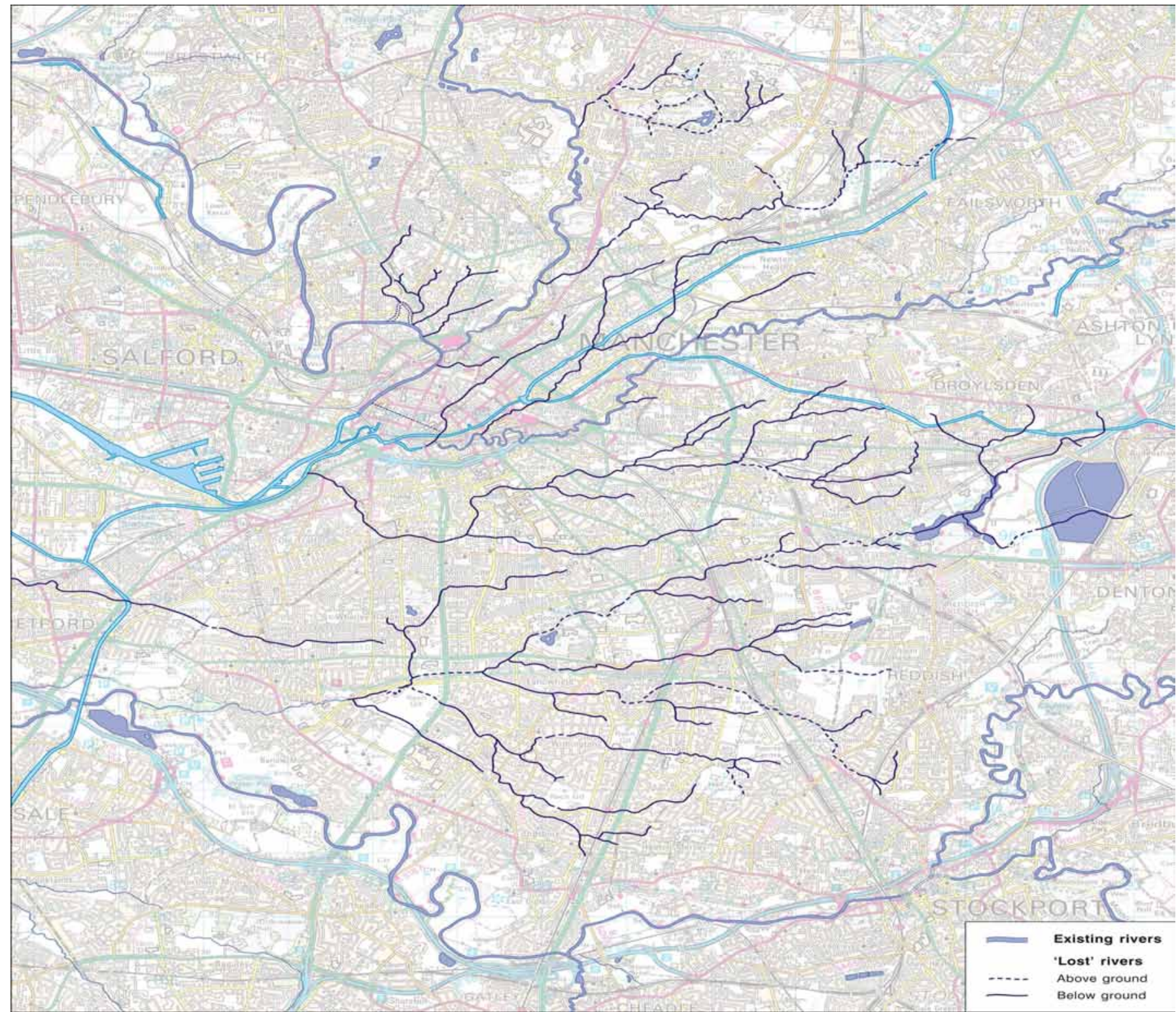

Figure 1: The results of a couple of hundred years of hydraulic engineering have forced many rivers out of sight in culverts and underground. (Source: Drawn by Nick Scarle, Carto Unit, University of Manchester, based primarily on data from Ashworth, 1987.) 
Figure 2: Lower level underground construction of sewers under existing streets. Note, photographic copy of poor quality original. (Courtesy of the Greater Manchester County Record Office.)

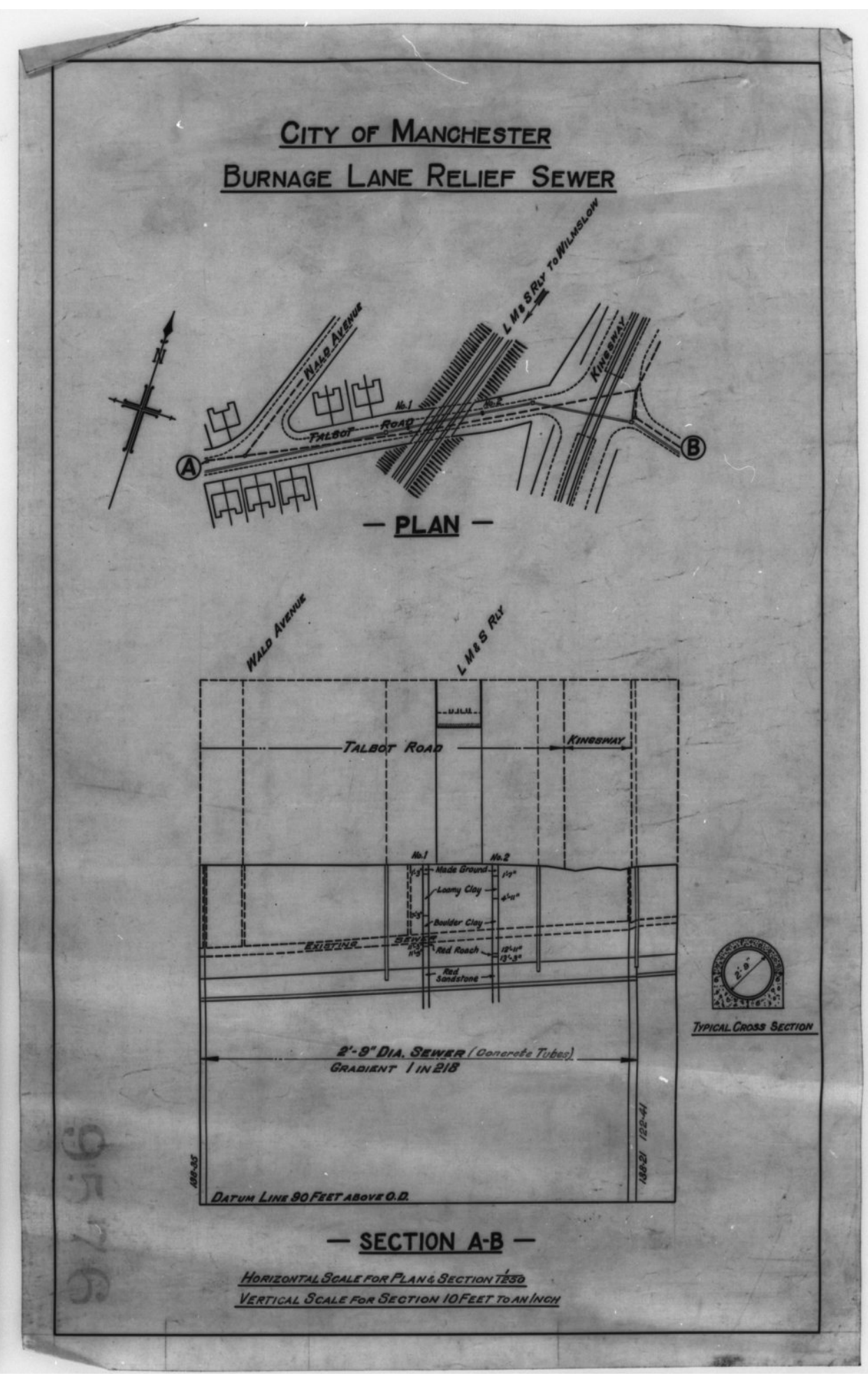




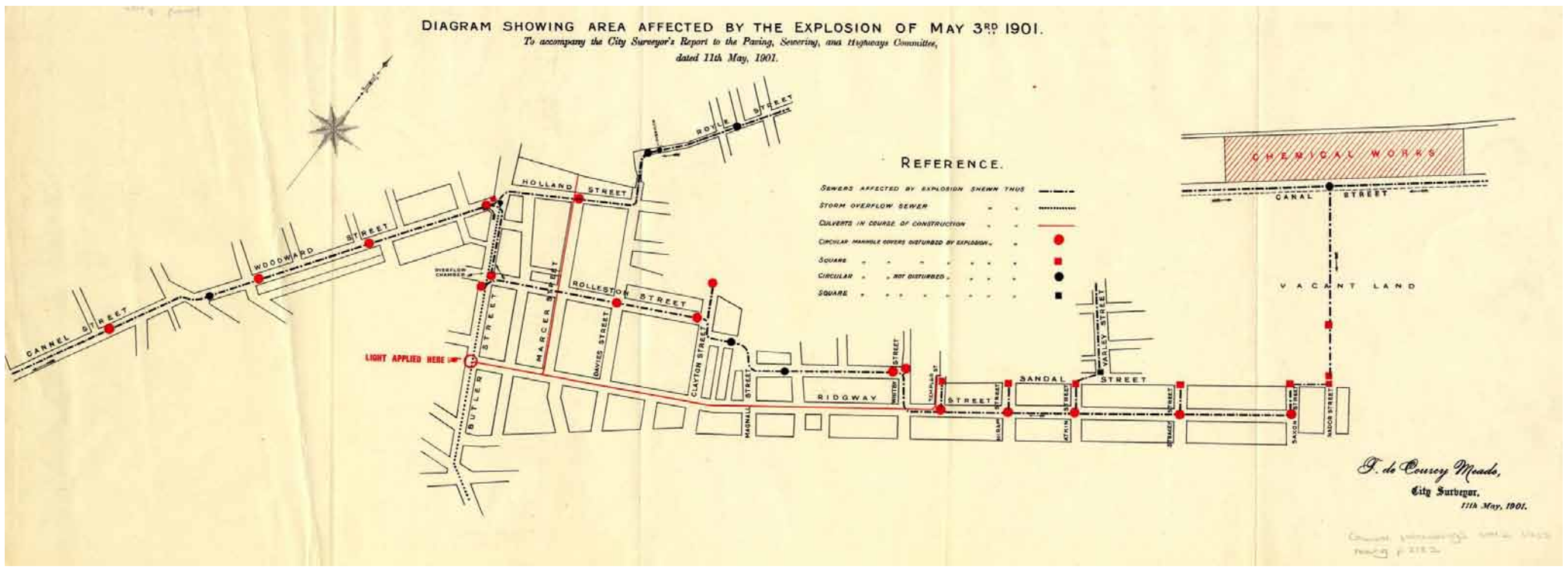

Figure 3: Mapping the impact of a sewer explosion event. (Source: Manchester Council Proceeding, 1902, Volume 2, p. 2182. Courtesy of Manchester Archives and Local Studies Library.)

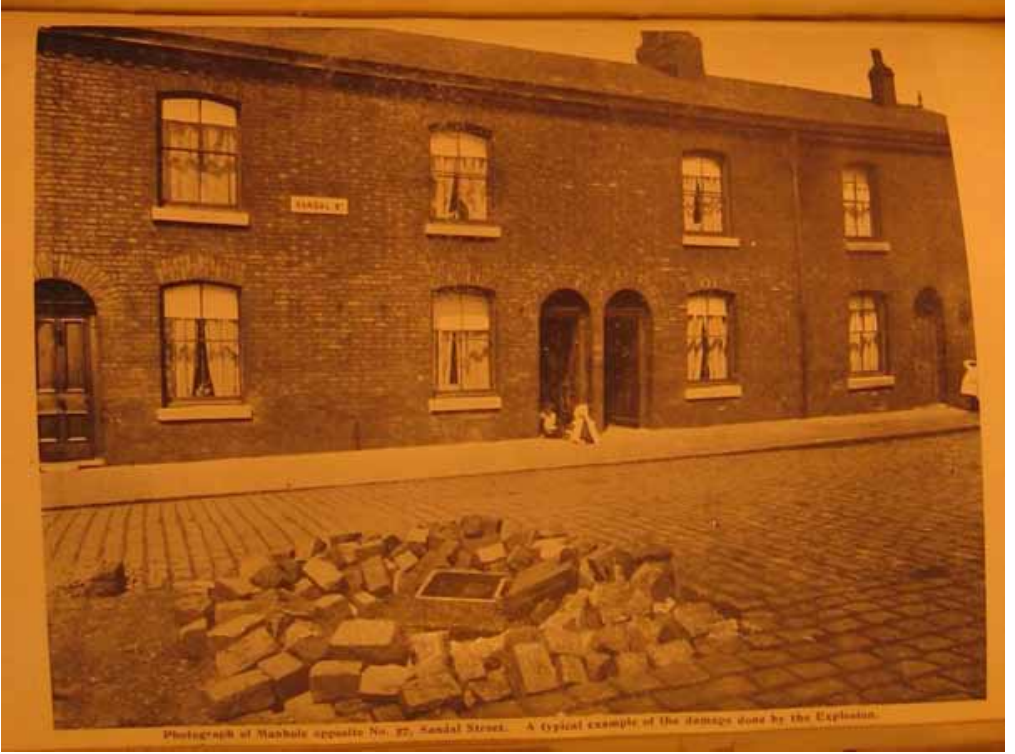




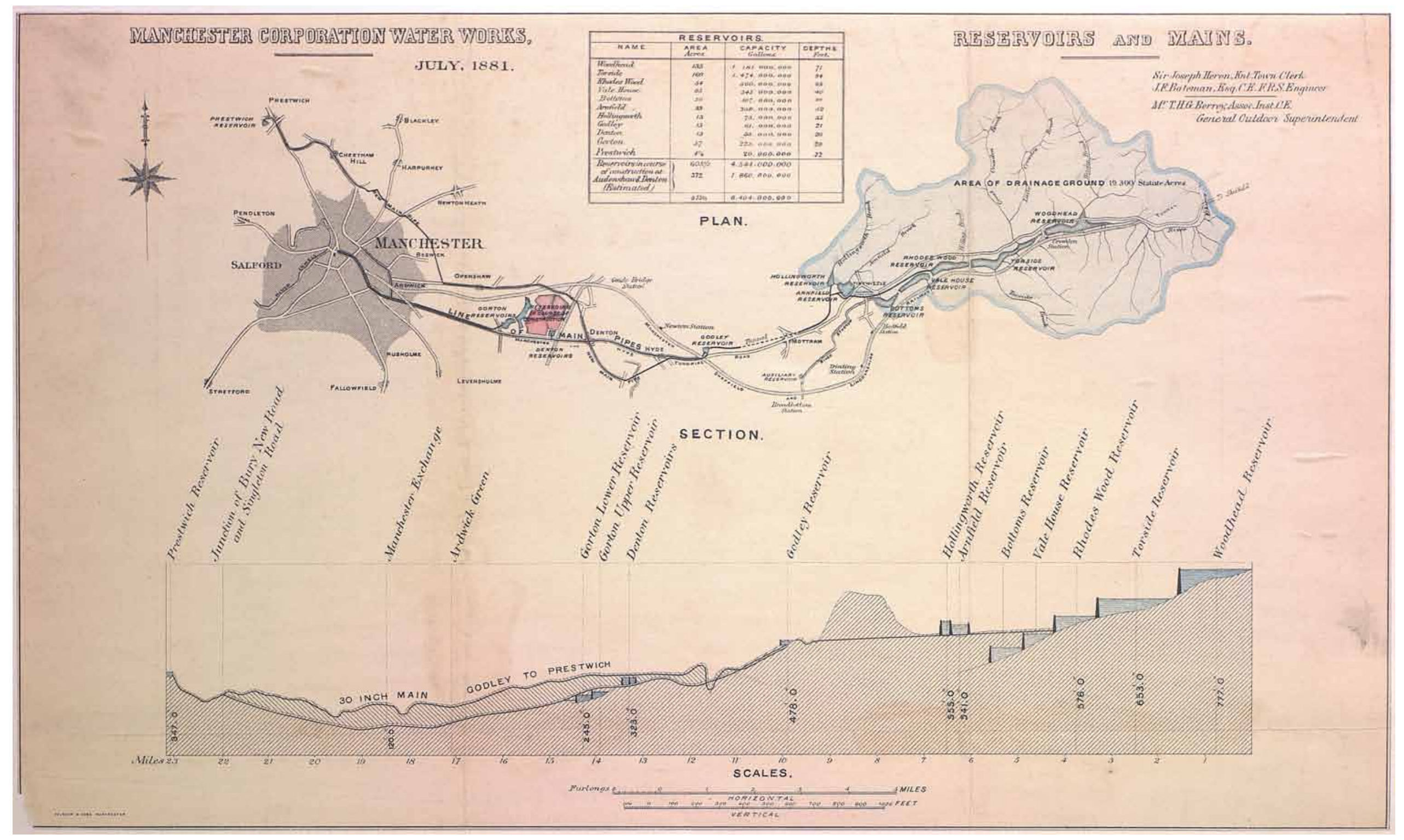

Figure 4: The Longdendale water supply system envisioned in map, section and tabular form. (Courtesy of Manchester Archives and Local Studies Library.) 
Figure 5: Mapping the aqueduct routes from the massive Lake District reservoirs to Manchester, 1917. The sheer scale of the hydraulic engineering represented is impressive (Courtesy of Manchester Archives and Local Studies Library.)

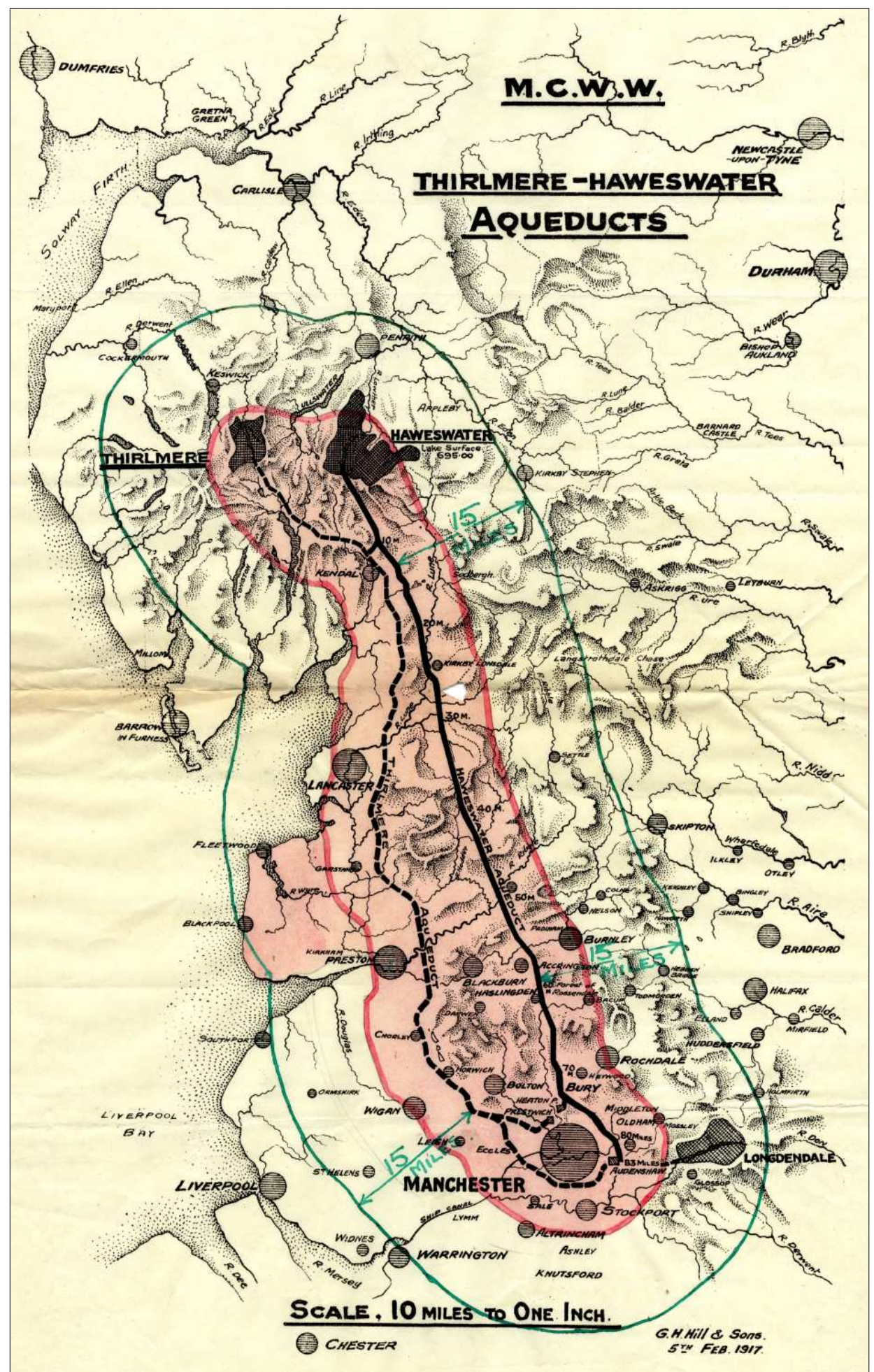


Figure 6: Local sewers drawn onto OS base map. Note, photographic copy of poor quality original artefact.

(Courtesy of the Greater Manchester County Record Office.)

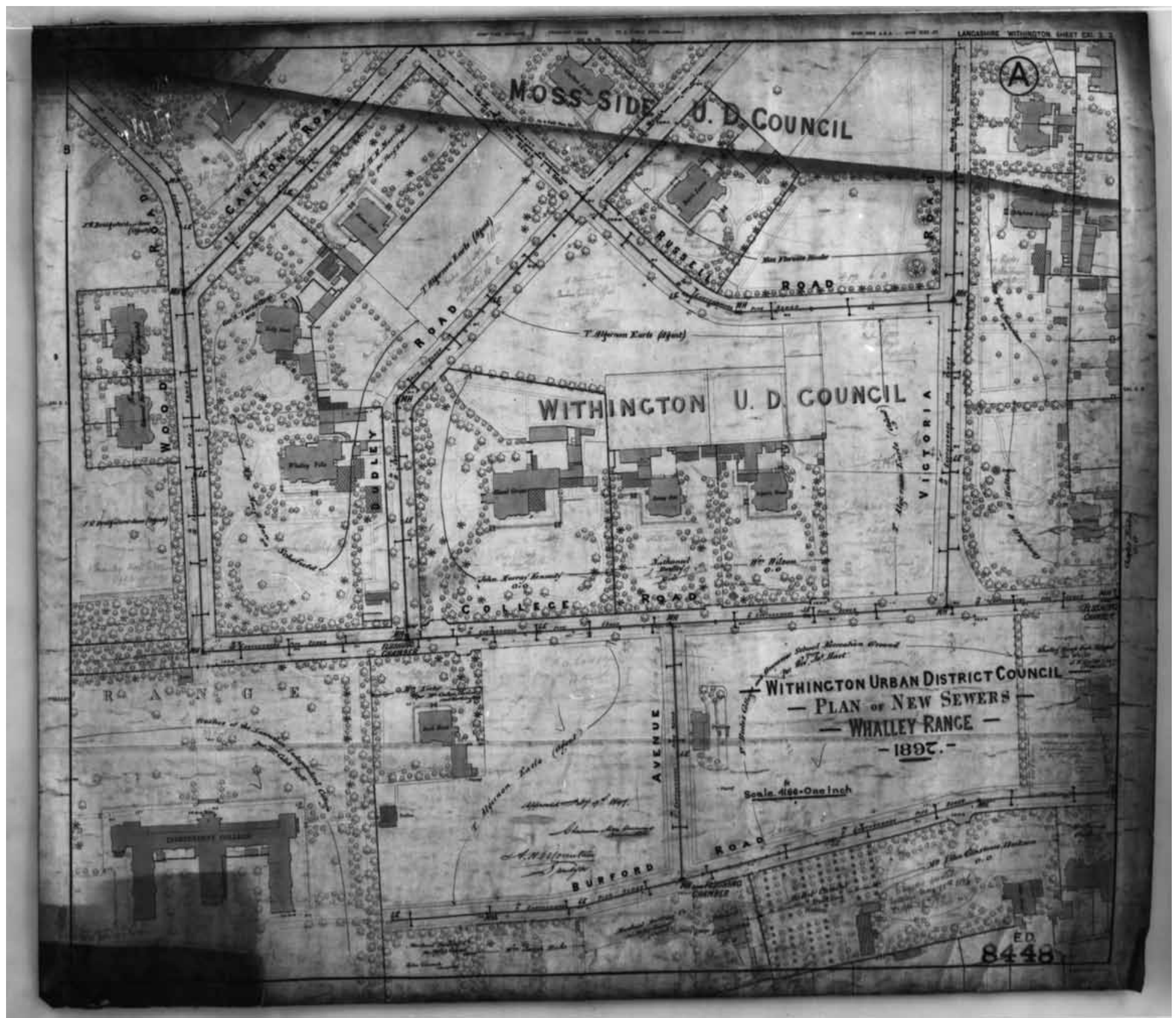




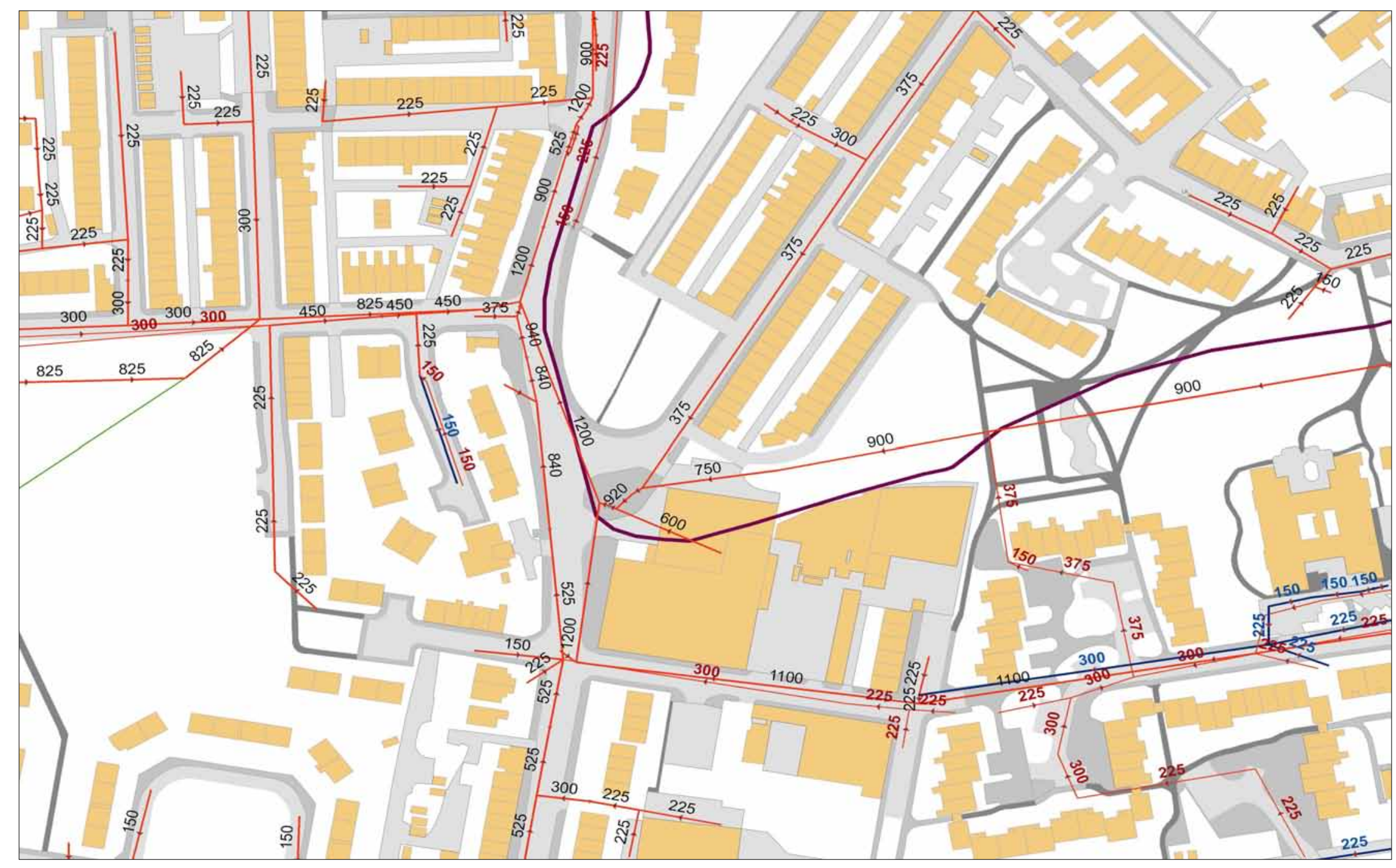

Figure 7: Screen image of contemporary sewer mapping by United Utilities. (Courtesy of Nigel Lawson.) 
Figure 8: General overview of major interceptor sewers in early $20^{\text {th }}$ century. (Courtesy of Manchester Archives and Local Studies Library.)

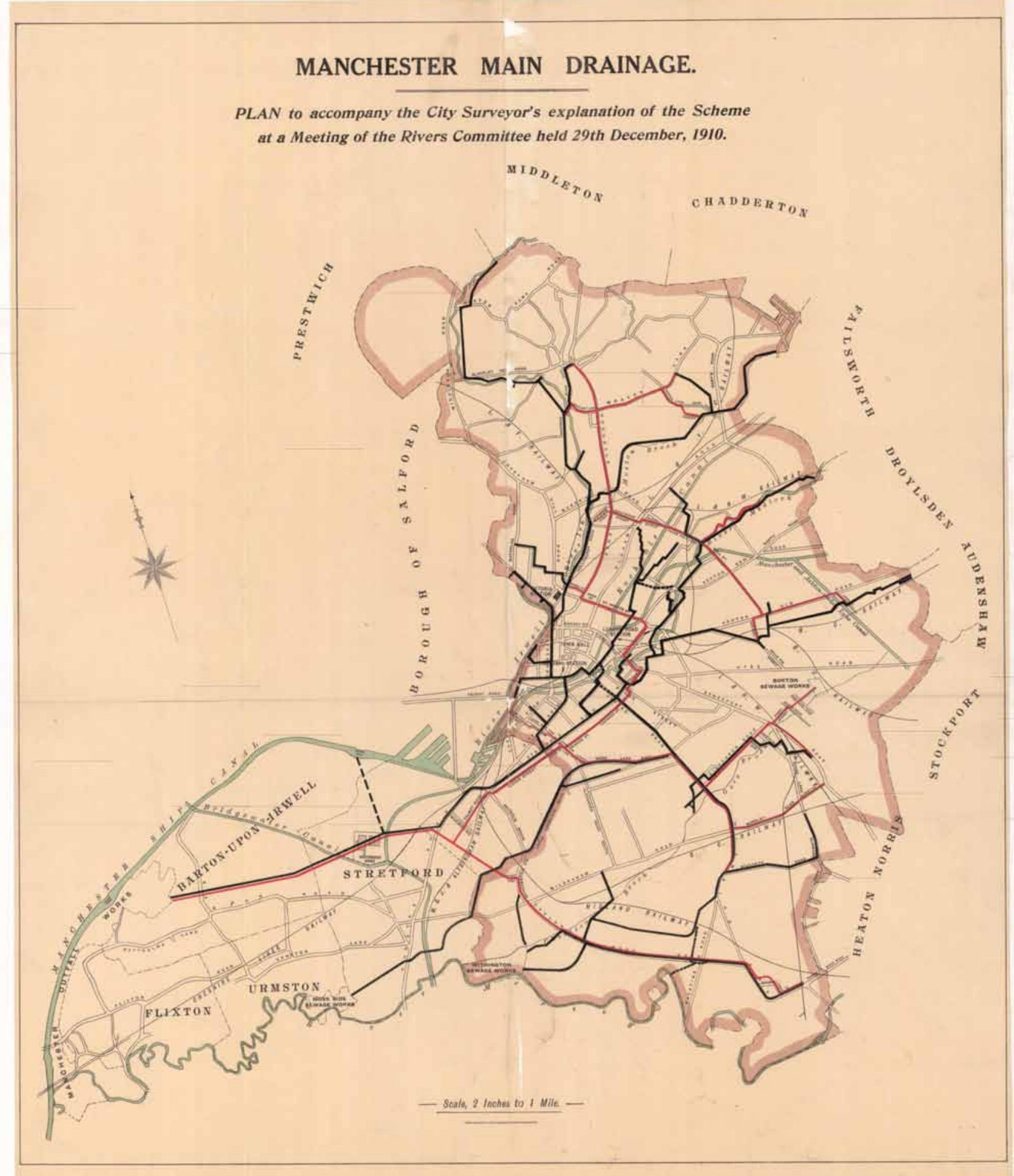


Figure 9: Flow chart of sewage processing (Source: How Manchester is Managed, 1934, page 117.)

\section{MANCHESTER CORPORATION - RIVERS DEPARTMENT}

DAVYHULME SEWAGE WORKS

: Diagram OF SEWAGE TREATMENT OPERATIONS :

OUTFALL SEWERS

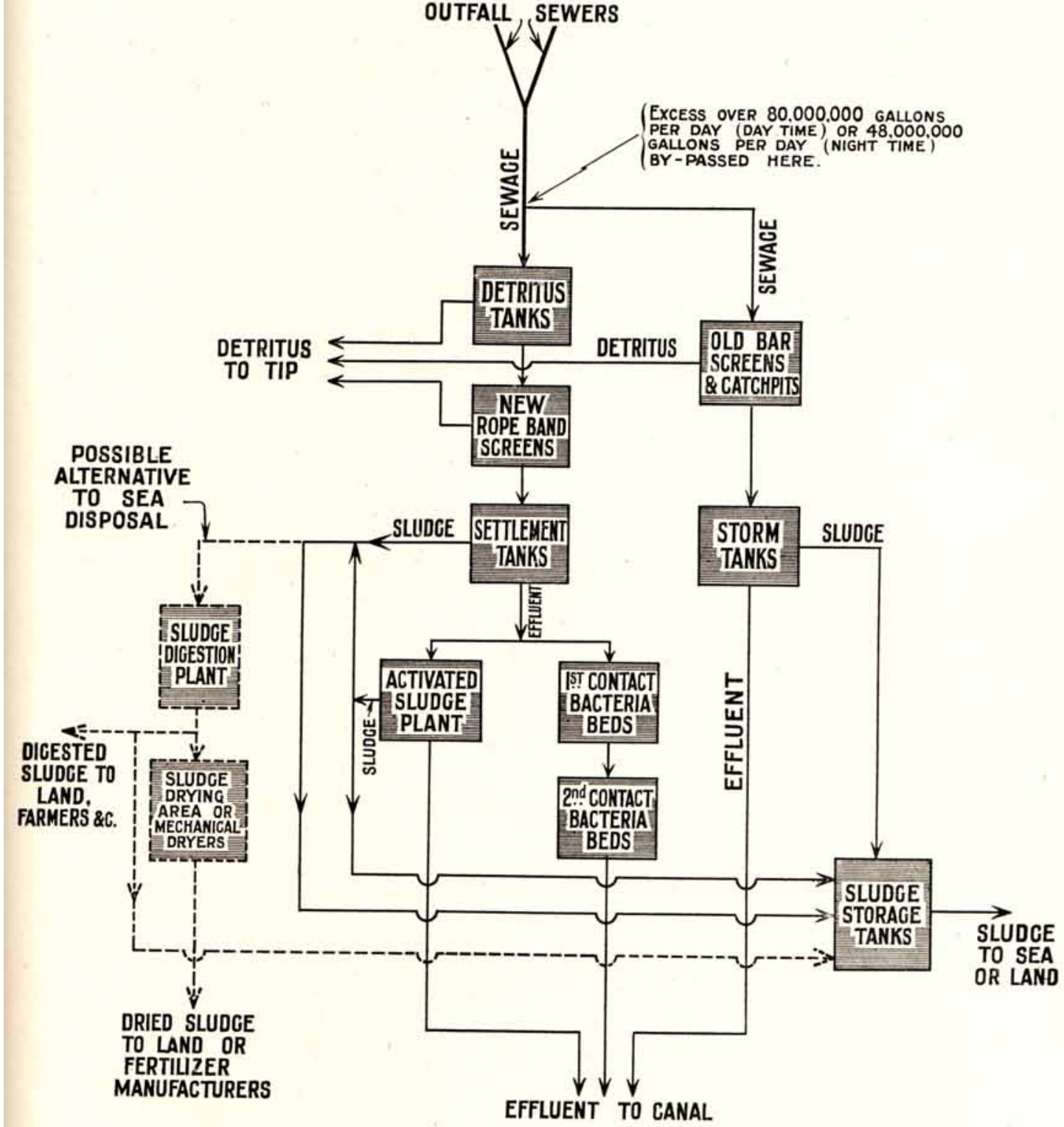




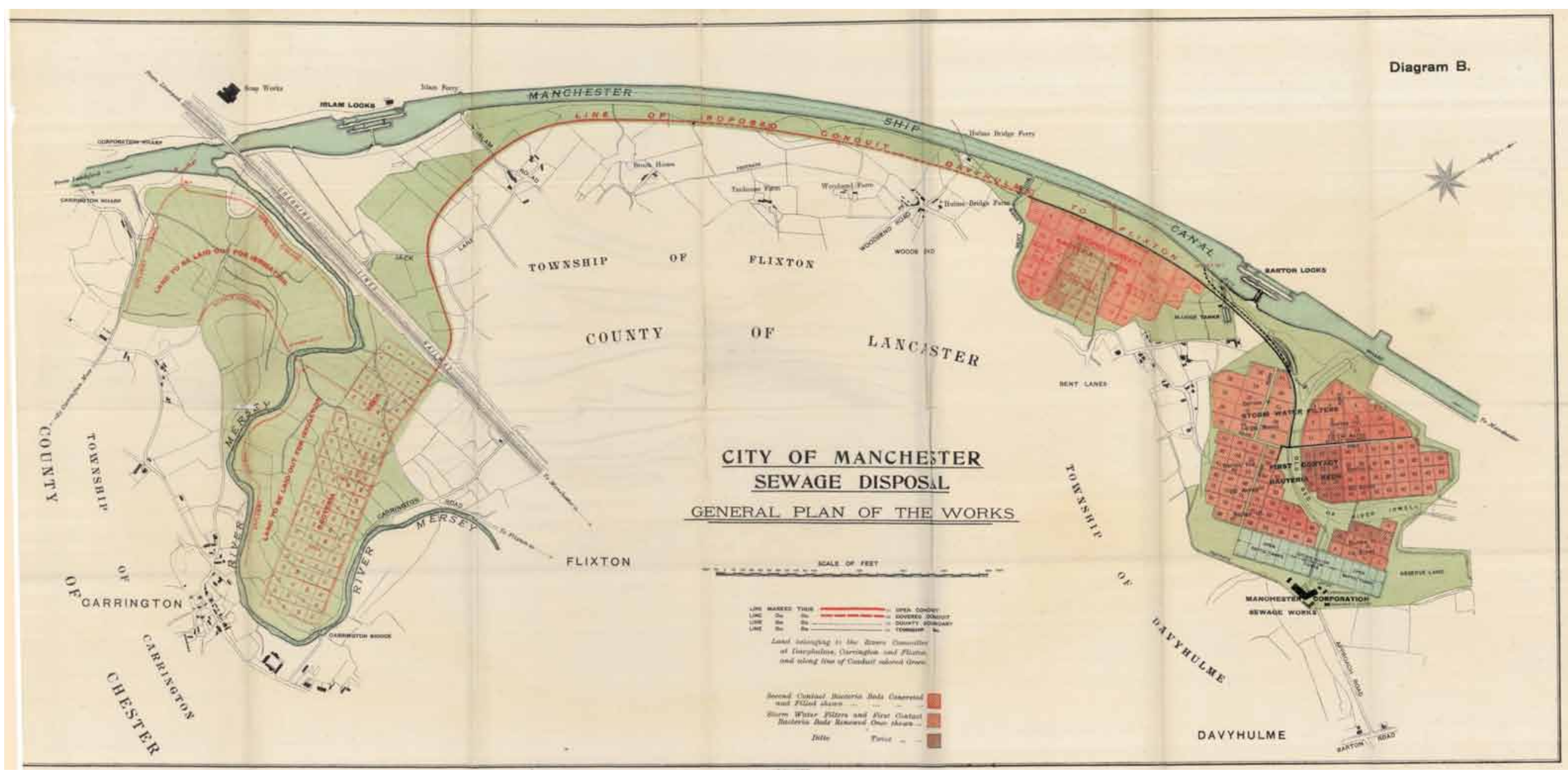

Figure 10: Davyhulme Sewage Works (Source: Annual Report City of Manchester Rivers Department, 1916. Courtesy of John Rylands University Library.) 


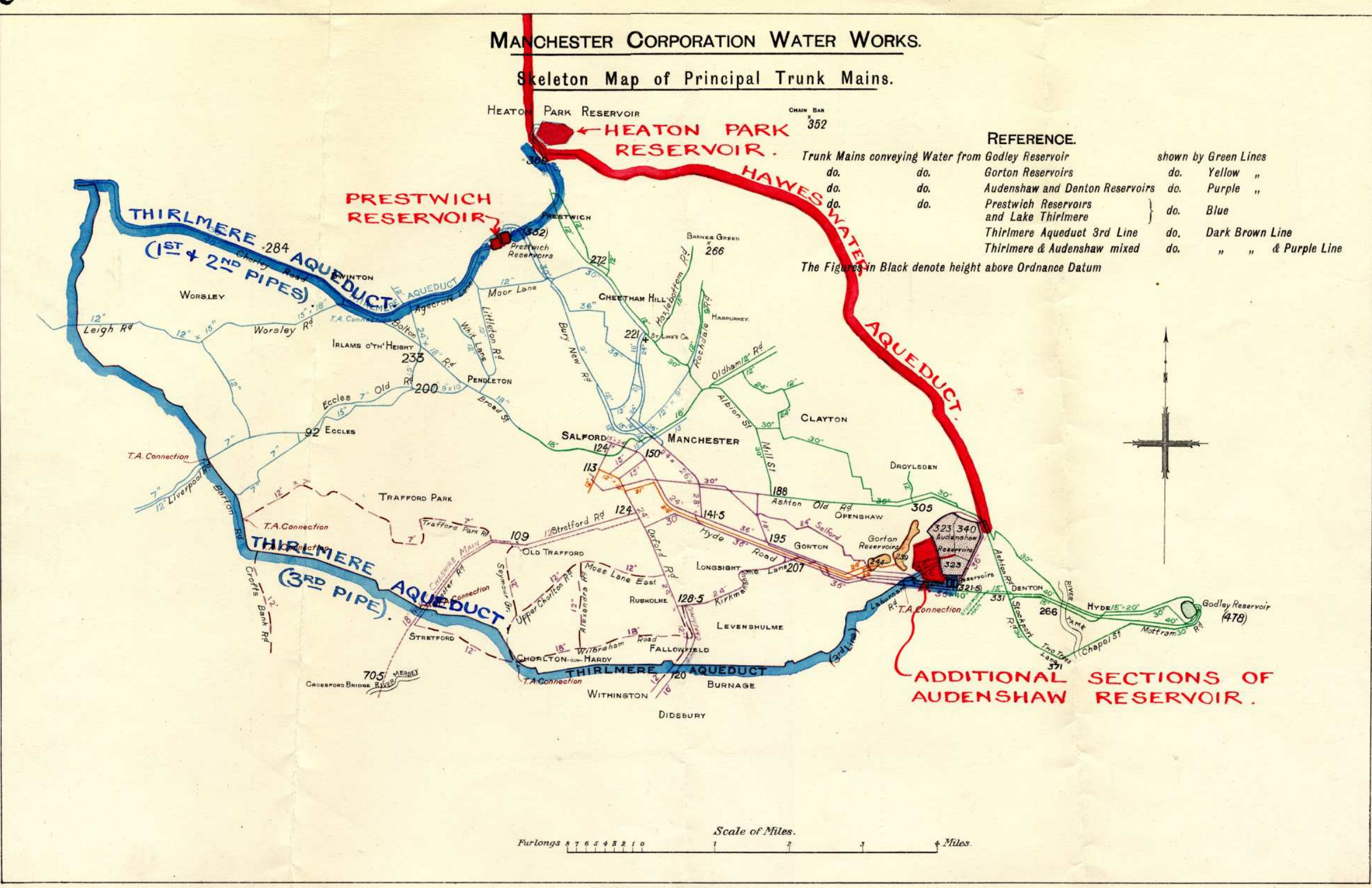

Figure 11: Mapping the addition of a major ring main around the city to distribute water from Lake District (Courtesy of Manchester Archives and Local Studies Library.) 


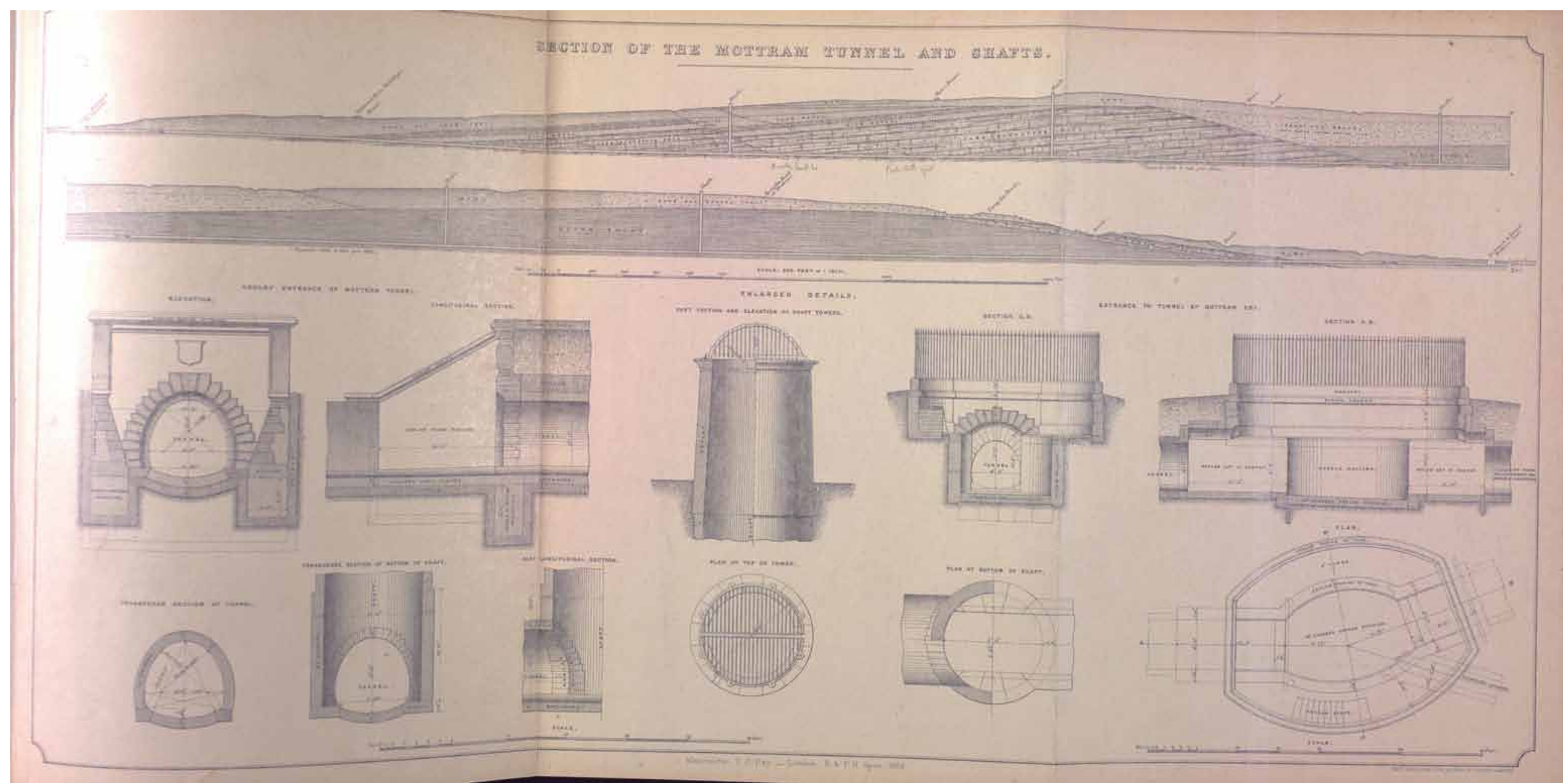

Figure 12: Sectional plan for Mottram tunnel, a crucial element in Bateman's gravitybased scheme to deliver drinking water from Longdendale to Mancheser. (Source: Plan included in Bateman, J.F. 1884 History and Description of the Manchester Waterworks. Courtesy of John Rylands University Library.) 


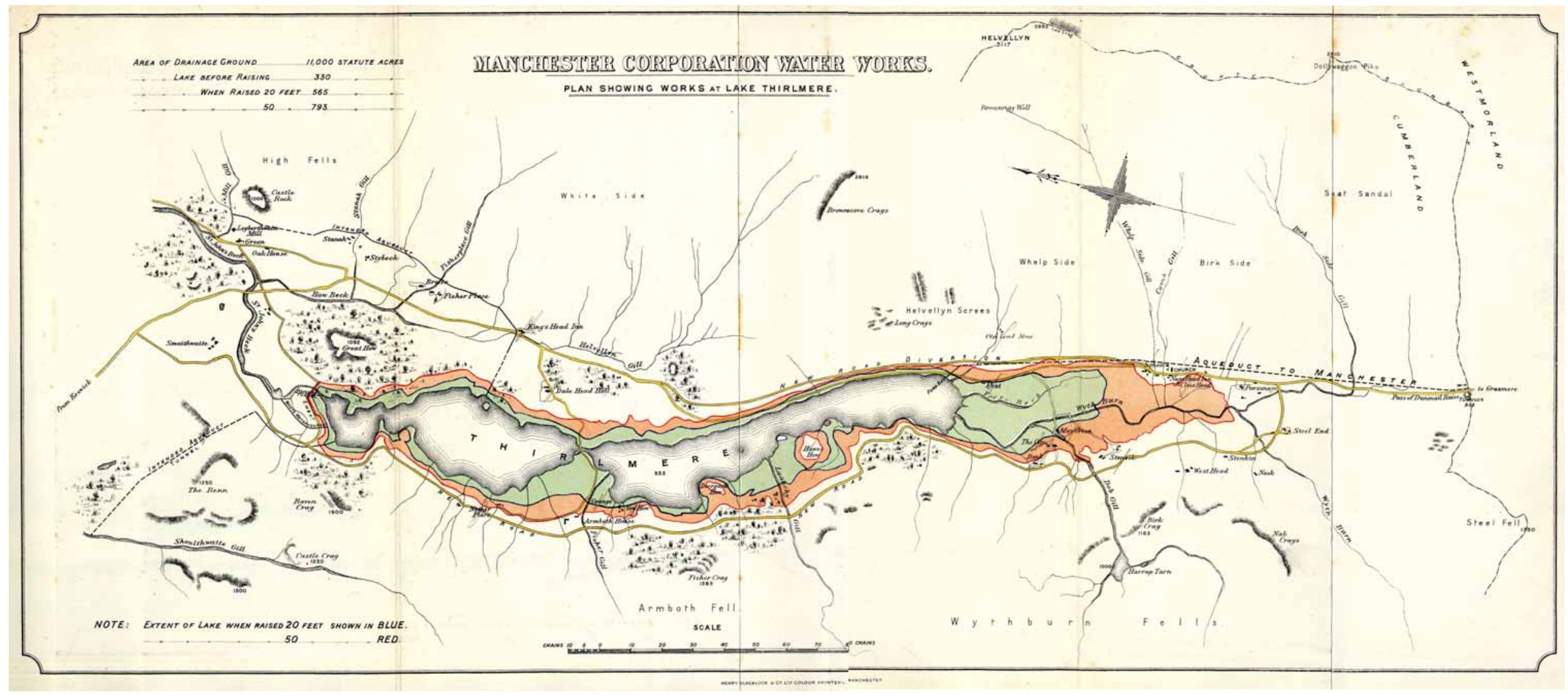

Figure 13: Changing Thirlmere from a lake to a controlled reservoir. (Source: Insert map included in Harwood, J.J. 1895 The History and Description of the Thirlmere Water Scheme. Courtesy of John Rylands University Library.) 


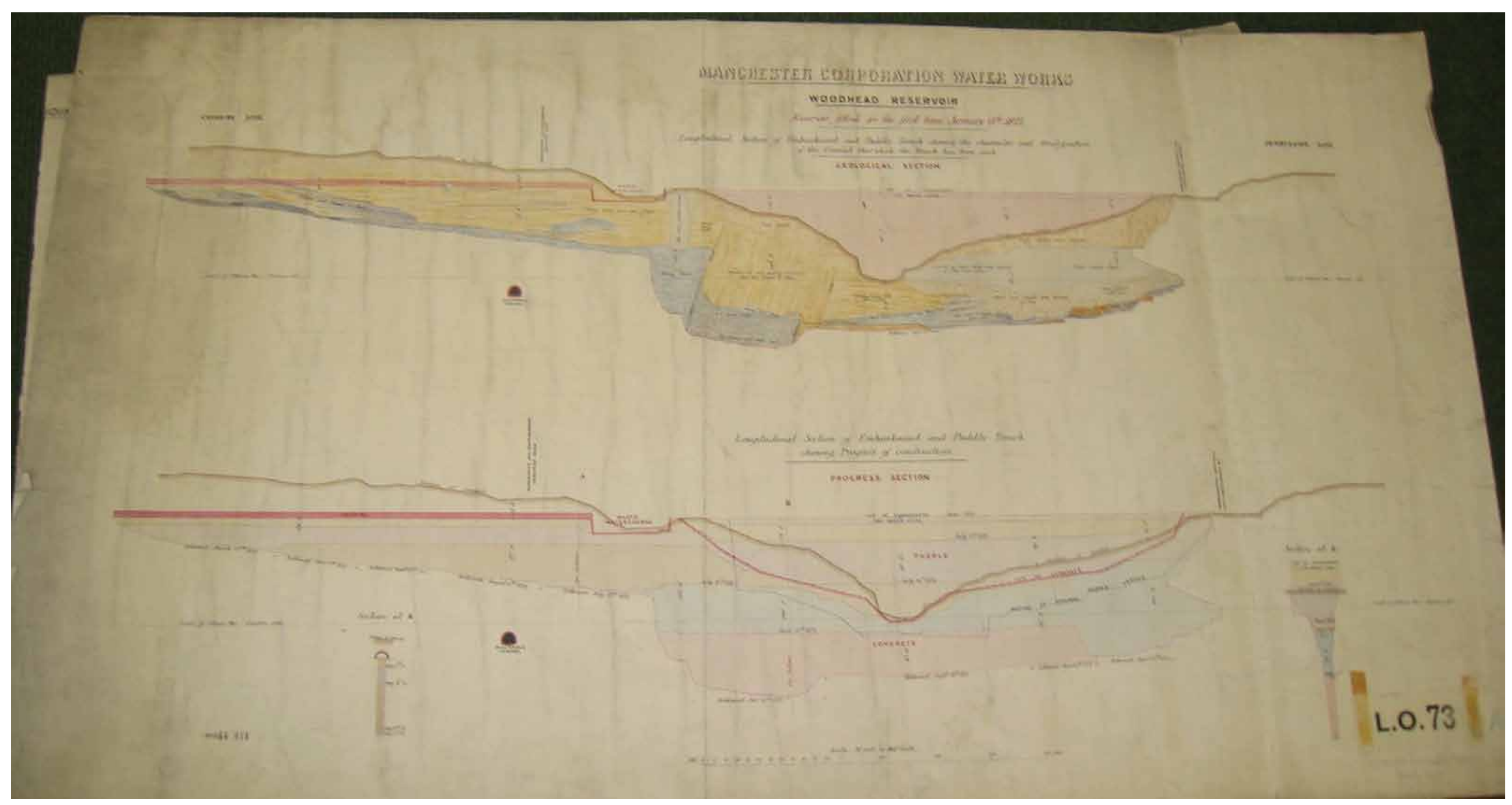

Figure 14: Sectional plans of second Woodhead dam. (Courtesy of United Utilities, Longdendale Bottoms office.) 


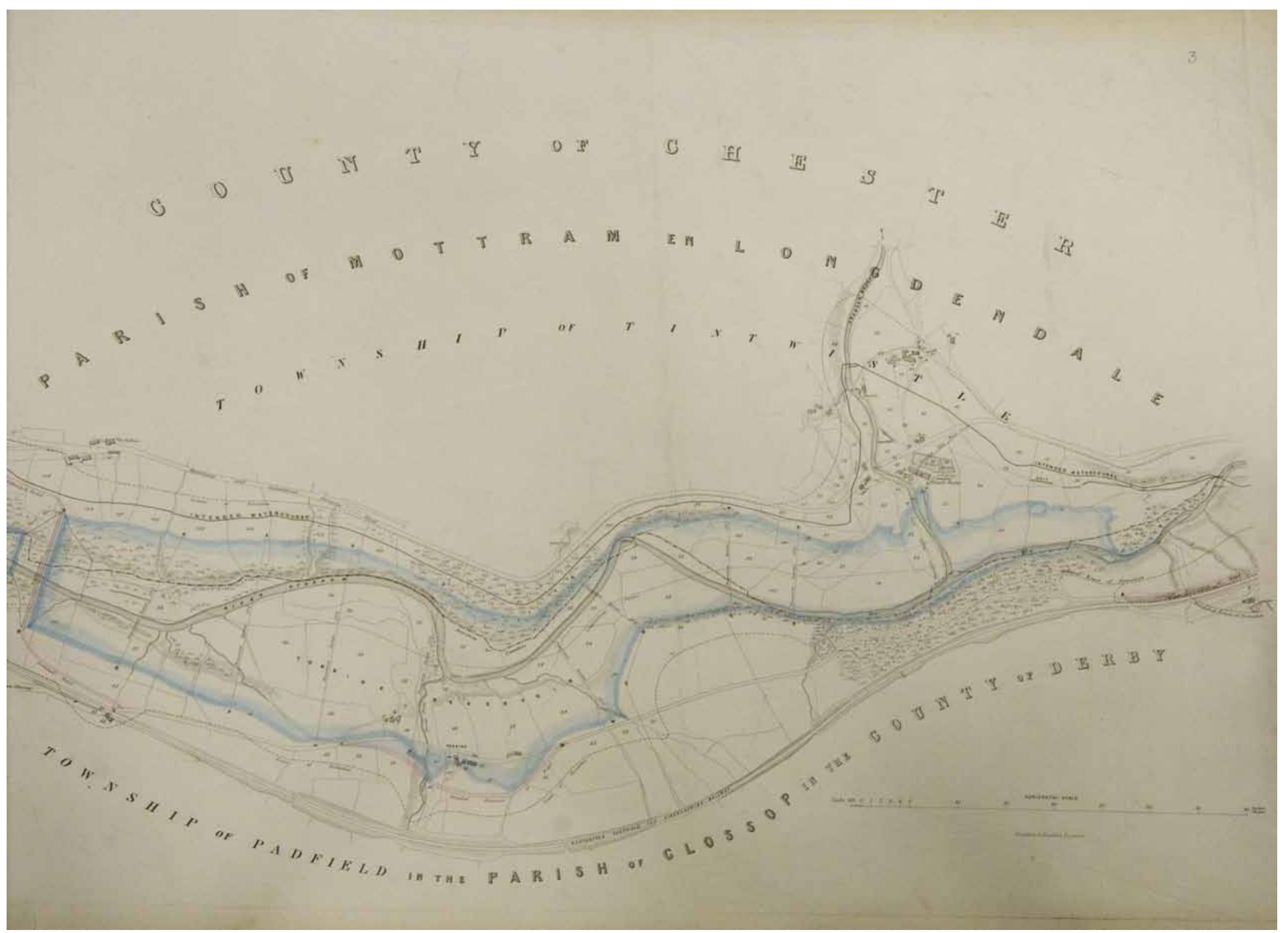

Figure 15: Original Parliamentary plan detailing the extent of the proposed Torside reservoir. (Courtesy of United Utilities, Longdendale Bottoms office. Photographic capture by Ben Lycett.)

MANCAESTER CORPORATON MATERTORKS

Buterided Sitenstori Wortis: BOROUGH of MANCHIESTER stssiov ar ists 
THE I IRWELL: AS A THOROUGHFARE.

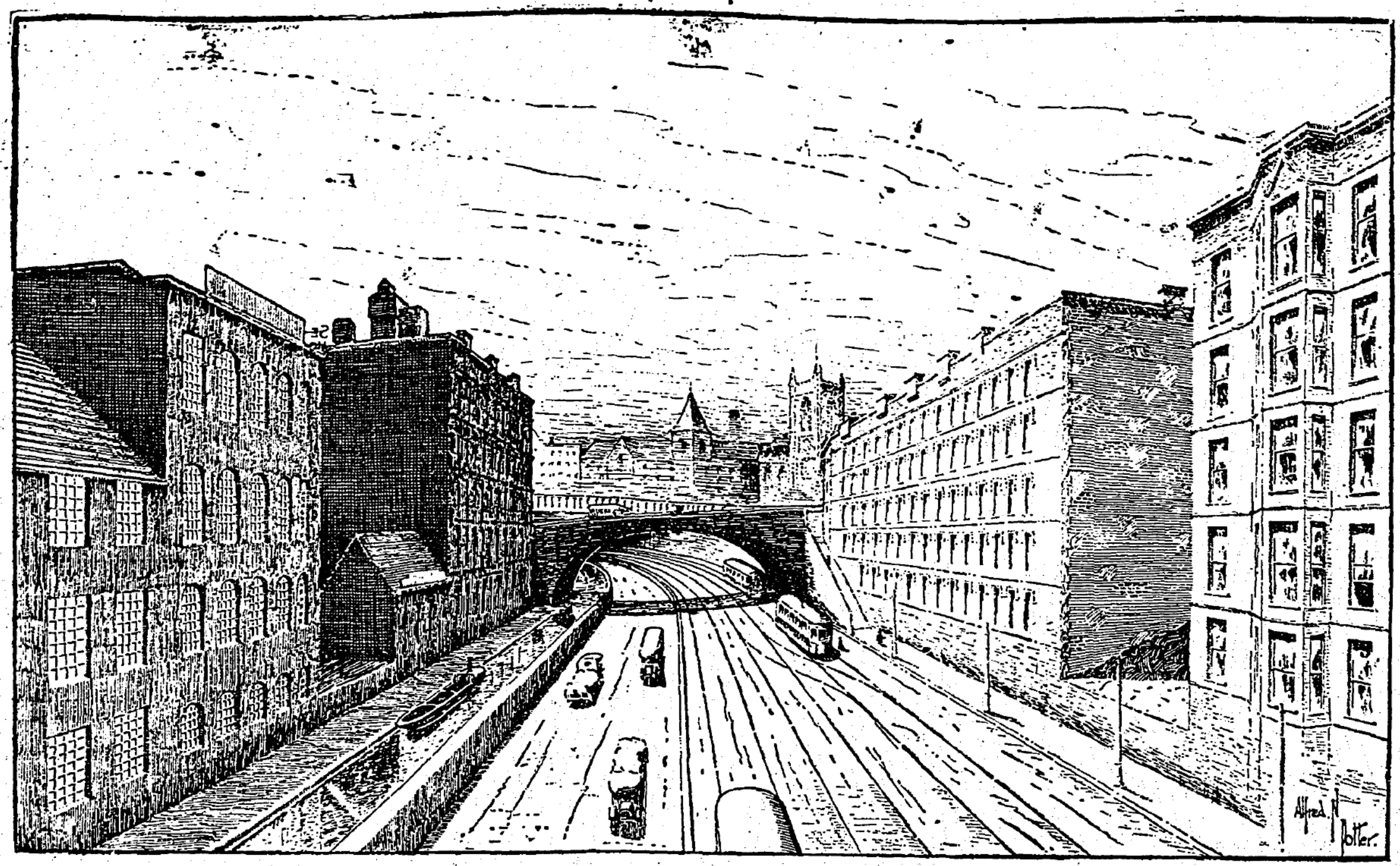

The old bed of the Irwell as it would appear if the scheme described in the adjoining article were carried out.

Figure 16: Unrealised plan to divert and drain the River Irwell between Salford and Manchester. (Source: Manchester Guardian, $1^{\text {st }}$ February 1924, page 10.) 